DEUÍFD Din Piskolojisi Özel Sayls1 / 2016, ss. 337-360.

\title{
ARAPÇA VE FARSÇA TARİH VE SEYAHAT METİNLERINNDE YOGİ DEĞERLENDİRMELERİ
}

\author{
Yazan: Carl W. Ernst* \\ Çeviren: Mehmet Atalay ${ }^{* *}$
}

ÖZ

Bu makalede, Arapça ve Farsça yazılmış çeşitli tarih ve seyahat metinlerinde yer alan bazı başlıca yogi değerlendirmelerine yer verilmekte ve bu değerlendirmeler kisaca analiz edilmektedir.

Anahtar Kelimeler: Yogi, Yoga, Hint Spiritüalitesi, Mistik Tecrübe.

\section{ACCOUNTS OF YOGIS IN ARABIC AND PERSIAN HISTORICAL AND TRAVEL TEXTS}

\section{ABSTRACT}

In this article, some major accounts of yogis that appeared in the various Arabic and Persian historical and travel literature will be put forth and shortly evaluated.

Key Words: Yogi, Yoga, Indian Spirituality, Mystical Experience.

Uzun yüzylllar boyunca Hindistan, garip ve ilginç olayların ülkesi olarak temayüz etmiștir. Büyük İskender'in yaşadığı dönemden bu yana seyyahlar ve tarihçiler, Hindistan'ın doğal güzellikleri, tarihi ve kültürü üzerinde yorumlar yapmışlardır. Zahitler ve haşin dini simalar, üzerinde yorum yapılması açısından daima popüler konular olagelmiştir; fakat, yabancı ziyaretçilerin bu Hintli münzevilerin manevi gayelerine ilişkin

* Prof. Dr. Carl W. Ernst, University of North Carolina'da (Chapel Hill) Din Bilimleri (Religious Studies) Bölümünde öğretim üyesi olarak çalışmaktadır. (Email: cernst@email.unc.edu). Makalenin ilk yayımlandı̆̆ı yer itibarıla künyesi şöyledir: Carl W. Ernst, "Accounts of Yogis in Arabic and Persian Historical and Travel Texts," Jerusalem Studies in Arabic and Islam, vol. 33 (2008), pp. 409-426.

** Doç. Dr. Mehmet Atalay, İstanbul Üniversitesi İlahiyat Fakültesi Felsefe ve Din Bilimleri Bölümü Din Psikolojisi Anabilim Dalı'nda öğretim üyesi olarak çalıșmaktadır. (E-mail: matalay@,istanbul.edu.tr). Bu makale, Prof. Carl W. Ernst'ün özel izniyle -ve kendi son yazdığı taslak esas alınarak- tercüme edilmiştir.

Makalenin Hakemlere Gönderiliş Tarihi : 12/01/2016

Makalenin Hakemlerden Geliş Tarihi : 11/03/2016 
olarak gerçek anlamda -basit ya da girift- herhangi bir anlayış edineceğine dair hiçbir teminat sözkonusu değildir.

Büyük İskender'in zahit Mandanis ile konuşmasına dair Megasthenes'in yaptı̆̆1 aktarım, Hintli çıplak filozof ya da yogilerle iletissimde ve özellikle de tercüme yoluyla iletissimde yabancıların tecrübe ettiği anlayış zorluklarını ele veren bir örnek işlevindedir:

Mandanis'in dediğine göre kendisi kralı methetmiştir. . çünkü kral, her ne kadar böylesine büyük bir imparatorluk idaresiyle meşgul ise de, hikmet heveslisiydi; çünkü kral, hayatı boyunca ilk kez gördüğü yegâne silahlı filozoftu; ve bu silahlı adamların, kendi kendini kontrol etmeyi öğrenmeye isteklileri ikna etme gücüne, isteksizleri de icbar etme gücüne sahip bilgeler olması bütün dünyada en faydalı bir şeydi; ama kral, lisan hariç olmak üzere kalabalık kitlelerden daha fazla bilgi sahibi olmayan mütercimler aracıllı̆̆yla konuştuğunda, kendi felsefesi itibarıyla herhangi bir şey ortaya koyamayacak ise mazur görülebilir; böyle bir şey, diye ekledi Mandanis, çamurların arasından akan suyun berrak akmasını beklemek demek olurdu!

Günümüzün eleştirel yazarları da, Hintli ‘öteki’ ile karşılaşmalarını anlatmaya çalışan Avrupalı seyyahların özellikle kendi oryantalist önyargı kalıplarını nasıl beraberlerinde taşıdıklarına işaret etmişlerdir. Din tarihçileri Hindistan dinleri hakkında bilgi edinmek amacıyla seyyah değerlendirmeleri ve tarihsel metinler üzerinde 'hafriyat' yapsa da, bu tür bir kazı işlemine ne ölçüde istinat edebileceğimize dair hiç kuşkusuz sınırlamalar sözkonusudur. ${ }^{2}$ Seyyah ister Avrupalı bir Hiristiyan isterse de Ortadoğulu bir Müslüman olsun, bu tür kaynaklar, itibari anlamda tartışılması beklenen konudan daha ziyade anlatıcının zihniyeti hakkında bilgi vermektedir. ${ }^{3}$

Öyle tahmin edilmektedir ki Hint dinleri üzerine Hint dünyas1 dışından insanların tuttuğu bu kayıtlardan istifade boyutlarının sınırlılığı,

\footnotetext{
1 Strabo, Geography, 15.I.64.

2 Avrupalıların yogiler hakkında serdettiği yorumlara ilişkin küçük bir seçki için bkz.: Yule \& Burnell, Hobson-Jobson, pp. 461-62, ("Jogee"). Avrupalı seyyahların yogi değerlendirmelerine ilişkin yeni bir veri toplamı için şuraya bkz.: Schmidt, Fakire.

3 Cole, "Mirror of the World"; Reis, Miroir, pp. 92-94.
} 
Müslüman seyyahların ve aynı zamanda Hintli-Müslüman hükümdarların ve onların tarihçilerinin muhasebelerine eşit düzeyde şamil olmaktadır. Hint dinlerine ilişkin olmak üzere bütün bu insanların ortaya koyduğu tasvirler; ekseriya "korku, hayranlık, aşinalık ve tiksinti duygularından müteşekkil tuhaf bir karışım sergilemektedir." Güney Asya alt kıtasında yoga öğretileriyle ilgili olarak bu kaynaklar ne kadar bilgi verebilir? Öncelikle belirtmek gerekir ki Vedanta kaynaklı metafizik, birkaç Müslüman filozofun hayranlığını celp etmiş olabileceği gibi yoga uygulamaları bazı heveskâr sufi mistiklerin ilgisini çekmişti. Oysa, gündelik ve sıradan gözlem imkânı itibarıyla bizzat yogi, Hint spiritüalitesinin en aşikâr -ve en egzotik- göstergelerinden biriydi. Simgesel bir ölüm tecrübesi aracılluğıla brahmin cemiyetinden ritüel anlamda bir kopma yaşayan yogiler, brahminlerin ve diğer üst sınıf Hinduların yabancılarla sosyal etkileşimini sınırlayan safiyet kurallarından bağımsız durumdaydı. Hindistan'da Türk ve Moğol hükümranlı̆̆ dönemlerinde bu çıplak ve kül renkli münzeviler; Müslüman hükümdarlar, devlet görevlileri ve seyyahların merakını cezbetmişti. ${ }^{6}$ Yogilerin celp ettiği dikkat, hiç şüphesiz ki kısmen meşhur gizemli güçleriyle alakalıydı. Hintli-Müslüman tarih metinlerindeki ve seyahat kayıtlarındaki değerlendirmelere ilişkin küçük bir tetkik; kuzey Hindistan'da genel olarak "cogi" diye telaffuz edilen Nath ya da Kanphata ("yarık kulak") yogilerinin, Güney Asya Müslüman 'âleminde' -şayet olağandışı değilse- kabul görmüş bir konum işgal ettiğini göstermektedir. Aynı zamanda ortaya çıkmaktadır ki birçok güçlü Müslüman hükümdar, faydalı buldukları belli başlı yoga uygulamalarına nisbeten aşina olmuşlardı. Dahası bu aşinalık, Bengisu Havuæünun (The Pool of Nectar) farklı versiyonlarının Arapça ve Farsça tercümeleri yoluyla

\footnotetext{
$4 \quad$ Alam \& Subrahmanyam, p. 291.

5 Müslüman yorumcuların Hint dinlerine dair değerlendirmeleri bağlamında sözkonusu olan problemlerle ilgili olarak şu makalelerime bkz.: "Situating Sufism and Yoga," "The Islamization of Yoga," "Muslim Studies of Hinduism?", "Admiring the Works of the Ancients."

$6 \quad$ Bkz.: Foltz; Green, pp. 210-11; Husain.
} 
yoganın metin düzeyinde olsa da İslam dünyasına kültürler-arası anlamda intikal etme sürecine paralellik arz etmekteydi. ${ }_{7}$

Uzun dönemler boyunca yogiler, Hindistan'daki garip ve şahane olaylara ilişkin "ister inan ister inanma" kategorisinde standart bir konumda bulunuyordu. Hindistan'a dair ilk Arapça seyahat kayıtlarından biri olarak 851 yilinda yazılmıs (ve zaman zaman Süleyman isminde bir tüccara isnat edilen) anonim bir metin, Hintli garip münzeviye ilişkin olmak üzere (burada tasvir edilen yogi için sözkonusu olduğu gibi) hiç değişmez olduğu düşünülen niteliklerle genel bir portre çizmektedir:

Ve Hindistan ülkesinde ormanlarda ve dağlarda dolaşan, çok az insanla görüssen ve ormanlardaki ot ve meyvelerle beslenen münzevi insanlar vardır. $\mathrm{Bu}$ kimseler, kadınlarla etkileşimi engellemek amacıyla cinsel organlarına demir yüzük koyarlar. Bazıları çıplaktır, bazıları da üzerlerinde kaplan derisinden başka hiçbir örtü olmadan sürekli güneşte kalır. Bir keresinde tıpkı az önce tasvir ettiğim koşullarda bir adam gördüm ve yanından ayrıldım. On altı yıl sonra tekrar aynı yere geldim ve bu adamı aynı halde buldum. Gözlerinin güneş ısısından mahvolmayışına hayret ettim. ${ }^{8}$

Yalnızlık, etsiz (vejetaryen) beslenme, cinselliğe karşı olağandışı tutum, çıplaklık ve güneşe bakmak dâhil olmak üzere daha sonra yogilerle irtibatlandırılacak birkaç tema bu iktibasta birlikte zikredilmektedir.

İslam tarihi kaynaklarında bulabildiğimiz kadarıla yoga, tıpkı gelecekten haber verme (divination) olgusu gibi Hint-İslam sultanlarının ilgisini çeken pratik bir konu olarak görülmektedir. Yogaya yönelik ilginin ideal anlamda Hint-İslam sultanlarına ilişkin tasvirlerin normal bir bileşenine tekabül etmemesi dolayısıyla, yogilere ilişkin ayrıntılı değerlendirmeler, saray vekâyinâmelerinde ancak nadiren yer almaktadır. Bununla beraber, idare merkezi saraylar ile müneccim ve büyücülerin işgal ettiği konuma benzer bir konum işgal eden yogiler arasında tahakkuk eden uzun süreli irtibata gösterge işlevinde kanıtlar bulunabilmektedir. On dördüncü yüzyılda Delhi sultanlığının altın çağında, brahmin olmayan çevrelerden gelen karizmatik simalar, sarayda

\footnotetext{
Briggs, Gorakhnath; Ernst, "Islamization."

8 Sulayman, 'Abbar as-Sin wa l-Hind, \$52, pp. 22-23.
} 
muayyen bir itibar kazanmıştır. Şair Emir Hüsrev (vef. 1325), Noh Sipihr (Dokuz Cennet) başlıklı Farsça destanının üçüncü bölümünde yer verdiği Hindistan'ın faziletlerine dair methiyesinde, Hint münzevilerinin doğaüstü güçlerine övgü düzmektedir. Emir Hüsrev, özellikle, brahminlerin gelecekten haber verme yetenekleri ile yogilerin nefes tutma maharetlerinin önemini vurgulamıştır. ${ }^{9}$ Caynist (Jainist) kaynaklara göre, Sultan Muhammed İbn Tuğluk, Caynist türbeleri tamir etme ve bunların korunmasını sağlama konusundaki gayreti vesilesiyle meşhur Caynizm âlimi Jinaprabhu Suri'ye imtiyaz ihsan etmiştir. Sultan, Suri'den yantra şekilli [tantrik meditasyona yardımcı olduğu düşünülen geometrik bir Hindu grafiği] bir koruyucu muska almış ve -Bengisu Havuzu'nda (The Pool of Nectar) da görülen bir uygulama olarak- onun altmiş dört 'yogini' (bayan yogi) üzerindeki hâkimiyetini müşahede etmiştir. ${ }^{10}$ Meşhur seyyah İbn Battûta da Muhammed İbn Tuğluk'un yogilere ilgisini teyit etmiştir. Ayrıca, İbn Battûta'nın kendisi de yogiler ve yogilerin menkul mucizevi güçlerinden hayli etkilenmişti. "Yogi gizemi" değerlendirmesinde İbn Battûta şunları söylemektedir:

$\mathrm{Bu}$ topluluk harikulâde olaylar sergiler. Bunlardan biri, aylarca yemek yemeksizin ve içecek içmeksizin durabilmeleridir. Çoğu, yer altında kendileri için mağaramsı oyuklar kazdırmıştır. Bu oyuklar onlar yer altındayken yapılır ve bu oyuklarda sadece hava almaları için bir delik birak1lır. Yogiler bu oyuklarda aylarca kalırlar. Bir yoginin bir yil boyunca bu hal içinde kaldığını duydum. Mangalore şehrinde yogilerden tedrisat gören Müslüman bir adam gördüm. Bu adam için bir platform yapilmış ve bu adam yirmi beş gün boyunca yemek yemeden ve içeçek içmeden burada üstünde kalabilmişti. Ben ayrıldıktan sonra daha ne kadar kaldı bilmiyorum. Halktan çeşitli insanların anlattı̆̆ına göre bu yogiler, belli birkaç gün ya da ay boyunca yemeleri için misket büyüklüğünde yiyecek hazırlar ve bu zaman zarfinda ne başka bir yiyecek yer ne de bir içecek içerler. Gizli olaylardan haber verirler [yani, geleceği tahmin ederler]. Sultanlar bu insanlara tazimde bulunur ve memnuniyetle huzurlarına

\footnotetext{
9 Amir Khusraw, Nub Sipibr, ed. Wahid Mirza, pp. 192-94, trans. R. Nath \& Faiyaz 'Gwaliari', in India as Seen by Amir Khusrau, pp. 98-99.

10 Jhavery, Comparative and Critical Study of Mantrasastra, pp. 230-34.
} 
kabul ederler. $\mathrm{Bu}$ yogilerden bazıları kendilerini sebze yemeği ile sınırlandırırken diğer bazıları (böyle bir sınırlamaya gitmeksizin) sadece et yemekten kaçınırlar. Et yemeyen yogiler çoğunluktadır. Bu insanların en bariz özelliği, kendilerini disipline etmeleridir (riyâzet). Dünya ve nimetlerinden yana hiçbir şeye gereksinim duymazlar. Bunlardan bazıları herhangi bir insanı sadece bakışlarıyla öldürebilir. Halkın anlattığına göre bir kimse bunlardan birinin bakışıyla öldüğünde naaşının göğsü yarılırsa kalbinin yerinde olmadığı görülür. Yine bu insanların dediğine göre sözkonusu ölü bedendeki kalp, 'yenmiş' bulunmaktadır. Bu durum kadınlar (kadın yogiler) arasında yaygındır ve bunu yapan kadına da 'sirtlan' tabir ederler. ${ }^{11}$

Bir keresinde İbn Battûta, bir yoginin sarayda, bizzat sultanın önünde havada uçtuğunu görmüss ve afallamıştı. Ayrıca İbn Battûta, Seylan'daki Adem Tepesi'ne (Adam's Peak, Cebel-i Âdem) dört yogi ile birlikte seyahat etmişti. ${ }^{12}$ Anlaşılan o ki, Malva'nın Halcî aristokrasine mensup bazı insanlar yoga yoluyla kazanılacağ1 düşünülen uzun ömür vaadine ilgi duymuşlardi; çünkü, söylendiğine göre bu insanlar, yoga tekniklerini öğrenmek, beden sağlığına ve hatta 'cinsel uygulamalara' hâkim olmaya yarayan ilaçlar kullanmak amaciyla yogilerle birlikte yaşamışlardır. ${ }^{13}$ Geleceği öngörme (divination) bilgisi ve yogini denen dişi ruhlarla iletişim kabiliyeti, on altıncı yüzyılın sonlarına doğru Gücerat bölgesindeki askeri seferlere komuta eden Müslüman hükümdarlar tarafindan faydalı bulunmaktayd.$^{14}$

Moğol imparatoru Ekber Şah'ın, değişik dinleri araştırma yönündeki meşhur temayülü dolayısıyla, yoga uygulamasına ilgili ve heveskâr olduğunu da tesbit etmek şaşırtıcı olmayacaktır. Saray görevlisi Beda'uni'nin olumsuz bir değerlendirme olarak kaydettiğine göre Ekber

11 Ibn Battutah, Voyages, ed. Defremery and Sanguinetti, IV:35-36.

12 Ibn Battutah, Travels in Asia and Africa, pp. 225-26, 255, 257, 259.

13 Rizq Allah Mushtaqi, Waqi at-i Mushtaqi, MS Add. 11,633, British Museum, fols. 91b-92a, aktaran: I. H. Siddiqui, "Resurgence of Chishti Silsila," p. 71.

14 al-Ulughkhani, Zafar ul Walih, trans. Lokhandwala, I:333 (Arapça metin, p. 417), I:377 (Arapça metin, p. 470). (Bu metnin atıf yaptığımız yerlerinde, sözkonusu sanatlarda uzman olduğu düşünülen Hasan adında Dekkan'lı bir Müslüman, hükümdar huzuruna davet edilmektedir). 
Şah, 1583 yilında Agra yakinlarında hem Hindu hem de Müslüman fakirlerin beslenmesi amacına dönük olarak binalar inşa etmiştir. Çok sayıda yogi de bu mekâna akın ettiğinden, Ebu'l-Fazl'ın memurları bu yogiler için Cogipura (Jogipura) [“yogiler şehri"] diye tabir edilen geçici bir konut inşa etti. Ekber Şah onlarla meditasyonu, bedeni terk etme olgusunu, yanısıra, simya ve büyünün etkilerini tartıştı. [Ekber Şah bu son iki uygulamaya (simya ve büyü) birbirleriyle kafiyeleşen kelimeler olarak kimya, simya ve rimya kelimeleriyle göndermede bulunmuştu]. Bu yogiler de Ekber Şah'ın uzun bir ömür yaşayacağı yönünde kehanette bulunmuşlardı. Ayrıca bu yogiler, Ekber Şah'a, et tüketimi ve cinsellik düşkünlüğünü sinırlaması gerektiği yönünde tavsiyede bulundular. Beda'uni’nin izlenimine göre yogiler Ekber Şah üzerinde bu bağlamda ölümcül düzeyde olumsuz bir etki bırakmışlardır. Beda'uni'nin daha sonra dile getirdiği iddiaya göre Ekber Şah, kendi müritlerine, yogiler tarafindan kullanılan bir terim olarak çile (chelab) diye tabir etmeye başlamıștır. ${ }^{15}$ Ebu'l-Fazl, Bengisu Havuzu'nun VII. bölümünde tasvir edilen büyücülüğe benzer bir büyücülük sanatının belli brahminlere isnat edildiğini tesadüfen fark etmiştir. Anlaşıldığı üzere bu büyücülük sanat1, geleceği tahmin etmek amaciyla ölü bedenleri diriltmek üzere bedenden ayrılmış ruhları celp etme imkânı sağlamaktadır. O dönemden geriye doğru dokuz yüzyıl boyunca uygulanan bu tür bir kehanet ameliyesi, 1586 y1lında Ekber Şah'ın Keşmir'i fethini öngörmek amaciyla icra edilmişti. ${ }^{16}$ Beda'uni, Ekber Şah'ın yoga mantralarına ilişkin bariz uyarlama faaliyetine de dikkat çekmiştir. Ekber Şah muhtemelen bu uyarlama faaliyetini, Bengisu Havuz̨unda tarif edildiği şekliyle çeşitli gezegenlerle bağlantılı manevi varlıkları (deity) kontrol etmek amaciyla gerçekleştirmiştir: Ekber Şah “gece yarısında ve ilk şafak vaktinde, güneşi kendi isteklerine itaatkâr kılmak amacıyla, Hinduların kendisine öğrettiği heceleri mırıldanmaya başlıyordu." ${ }^{17}$ Ebu'l-Fazl, devlet yapıs1 ve müesseselerine ilişkin kendi tetkiki Â'în-i Ekberîsinde (آئين اكبرى) [ya da Ekber Müesseseleri], Patañjali’nin yogayla alakalı klasik metnine ilişkin bir

5 Bada'uni II: 324-25; çeviri nüsha, II:334-35.

16 Abul-Fazl Allami, Ekbernâme, I:507; çeviri nüsha, I:772-73.

17 Ibid., II: 261; çeviri nüsha, II:268. 
özet vermekte ama o dönemin yogilerine dair hiçbir şey söylememektedir. ${ }^{18}$

Ekber Şah'ın oğlu Cihangir, kendi hatıratında, bazı yogileri Peşaver yakınlarındaki Gorah Hatari'deki (Gorhatri ya da Gorahtari gibi çeşitli şekillerde telaffuz edilir) inziva mekânlarında arayıp bulma konusunda hayli heveskâr olduğunu kaydetmektedir. Evvelce bu mevki, Cihangir'in dedesinin dedesi Babür Şah tarafindan 1519 y1lında ziyaret edilmişti. Her ne kadar Babür Şah bu mekânın pek etkisinde kalmamış idiyse de hatıratının resimli nüshaları orada yogilerle karşılaşmış olduğunu göstermektedir. ${ }^{19}$ Cihangir'in ziyareti de eşit düzeyde hayal kırıcı nitelikteydi: "[Aslında] böyle bir kimse, anka kuşu ya da felsefe taşı kadar nadirdir. Ama benim bütün gördüğüm, sefil bir cahil sürüsüydü. $\mathrm{Bu}$ insanları görmekten tek kârım, kafa karışıklı̆̆1 oldu." ${ }^{\text {,20 }}$ Cihangir, yogilerle dostane olmayan bir tarzda karşı karşıya geldiğini de itiraf etmektedir. 1613 yilında, hac yolunda Acmer'deki Çeştî türbesini ziyaret ettikten kısa bir süre sonra Puşkar'da konakladı. Bir 'put kırıcı' psikolojisiyle Vişnu'nun avatarı olarak domuz şeklindeki bir putu imha etti. Sonra da, insanları aldattığından şüphelendiği bir yogiyi şehir dışına kovdu. ${ }^{21} \mathrm{Bu}$ olaya rağmen, tıpkı babası Ekber Şah gibi Cihangir'in de önde gelen yogilerle irtibat muhafaza etmeye çalıștı̆̆1 görülmektedir. ${ }^{22}$ Hindistan Pencap'ındaki Yahbar'da (Jakhbar) bir yogi türbesinde bulunan hasılat belgeleri mecmuası, bu müesseseyi koruma ve yaşatmaya yönelik olarak

18 Abu al-Fazl 'Allami, The A'in-i Akbari, trans. Jarrett, pp. 187-98.

19 Bkz.: Babur, Babur-nama, trans. Beveridge, p. 230. (Bu kaynak sözkonusu mevkinin adını Gur-hatri olarak vermektedir); Saiyid Rizvi, A History of Sufism in India, vol. 1, p. 369 (Bâbürnâme'nin Britanya müzesindeki nüshasından alınma bir resim). Bu mevkinin adının Sih kaynaklarına dayalı olarak Gorah Hatari şeklinde telaffuzu için bkz.: Digby, "Encounters with Jogis," pp. 29-30. Briggs, Gorhatri'nin Gorahsetra'dan türediğini söylemektedir (p. 98). Thackston, kelimeyi Gurh Katri diye telaffuz etmektedir (The Baburnama, fol. 232b, p. 285). Ayrica bkz.: Husain, p. 142, n. 1.

20 Jahangir, The Jahangirnama, trans. Thackston, p. 74; id., The Tu₹uk-i-Jahangiri, trans. Rogers, I:102.

21 Ibid., trans. Thackston, p. 153; trans Rogers, I:254-55.

22 Cihangir'in yogiler ve diğer münzevilerle karşılaşmaları için bkz.: Mobad Shah, Dabistan, pp. 146 (Akamnath), 155 (Chatur Vapa), 162 (Sri Kant); tercüme versiyonu için ayrica bkz.: Shea and Troyer, pp. 234, 247, 255. 
1581-1741 aras1 dönem itibarıyla Moğol hükümdarları tarafindan sağlanan resmi himaye konusunda ayrıntı vermektedir. Diğer birçok gayri Müslim dini merkez gibi bu yogi türbesi de teberru vakıfları idaresince sağlanan bağışlar yoluyla arazi geliri elde ediyordu. Bu yogi türbesinin yardıma nail olması, yogi üstatlarına kişisel olarak sayg1 gösterdiği anlaşılan Ekber Şah ve Cihangir tarafindan özellikle onaylanmıştı. Bu arada, 1661 yllında Alemgir Şah'ın bu türbedeki baş yogiye simya ilaçları istediği kişisel bir mektup gönderdiğini kaydetmek isabetli olacaktır. ${ }^{23}$ İngiliz seyyah John Fryer'ın iddiasını dikkate alacak olursak, Moğol idare sistemindeki bir açığın eyyamcı yogilerce istismar edildiğine dair göstergeler de sözkonusudur. John Freyer'ın suçlayıcı iddiasına göre "Fakirler", "Gayri Müslimler"den (Hindular), Hz. Peygamber'e hakaret ettikleri ithamına dayalı olarak şeriat mahkemelerine ihbar etmekle tehdit ederek bağış sızdırıyorlardı. ${ }^{24}$ Nath yogilerinin menâkıbnâme geleneği, Delhi sultanları ve Moğol imparatorları tarafindan gördükleri himayeye çok büyük önem atfetmektedir. Sözkonusu gelenek, yogilerle Delhi sultanları ve Moğol imparatorları arasındaki bu ilişkiyi hem kârlı hem de moral yükseltici bir ilişki olarak değerlendirmişlerdir. ${ }^{25}$

Farsça yazılmış coğrafya kitapları, söz arasında yogileri Hindistan'ın olağandışı bir özelliği olarak zikretmeye devam etmiştir. Emin İbn Ahmed Razi, 1954 yllinda yazdiğ1 Heft İklim (Yedi İklim: The Seven Climes) başlıklı gösterişli kitabında, Hindistan'ın harikalarına dair şimdi kayıp bir ilk kaynaktan aldığ1 ve yogilerin nefes alıp verme tekniklerini olduğu kadar daima popüler intihar (self-immolation: kendi kendini yakarak vs. kurban etme) hikâyelerini de içeren bir değerlendirmeye yer vermiştir:

Kendi zamanının yetenekli insanlarından biri olan Muhammed Yusuf Herevî, Hintlilerin harika ve nadir maharetleri üzerine bir risale yazmıştır. Bu zat şunları anlatmıştır: Hindistan eyaletlerinden birinde

23 Goswamy \& Grewal, The Mughals and the Jogis of Jakhbar.

24 John Fryer, New Account of East India and Persia (London, 1698), p. 95, aktaran: Schmidt, Fakire, p, 164.

25 Bouillier, Ascètes et rois, pp. 68-75, 116-18; Briggs, pp. 70, 92, 94-5, 105, 144; White, "The Wonders of Sri Mastnath." 
bulunuyordum ki bir yoginin oranın kralı önünde kendisini yakarak kurban etmek istediğini duydum. Bu eyaletin kralı üç gün boyunca ziyafet ve şenlik düzenledi. Dördüncü gün şafak vaktinde güneş doğu tarafindaki kalenin üzerinden görünüp adeta bir örtüyü andıran toz bulutunun üzerine sabitlenince, büyük bir putperest kalabalığ1 peydah oldu. Sonra, sırtında 'fenâ elbisesi', başında da 'feragat şapkası' olan bu yogi geçici varlıktan sıyrılıp hiç fânî olmayacak 'hiçlik' durumuna intikal etti. Kralın önüne geldi ve teşrifat âdetleriyle gerekli selamlamaları icra etti. Dudakları bir gül goncası gibi konuşmadan yana kenetlenmiş vaziyetteydi. Bu yogi o sırada ayakta duruyordu ve âdeta bir nergis çiçeği gibi ayaklarına bakıyordu. Görevliler keçi ve sığır tezeği seyreltmeye başladı ve bu yoginin bulunduğu mevkiye omuzlarıla baş hizasına gelinceye dek tepeleme yığdı. Sonra bu tezek yığını sağ ve sol taraflarından ateşe verildi. Alevler her yanı sardı ve ortalığ bir sicaklık kapladı. Âdeta bir kandil gibi yanan bu tezek yığınında alevler yoginin boğaz hizasına kadar yükseldi. Yogi krala döndü ve birkaç söz söyledi. Sonra da, boynunu niyazda bulunan biri gibi eğdi, alnını alevlere çevirdi ve gözlerini kapayıp son nefesini verdi. (Şiir:)

Öfkeli âşı̆̆ı başının altına bir tuğla koydu;

Öyle yandı ki en nihayet başını küllere yasladı.

Daha sonra, bir saat boyunca vücudunun parçalarını araştırdılar ama bir kül kalıntısından başka bir şey bulamadılar. (Şiir:) demektir;

'Kendi'nden bir parça 'yerli yerinde' değilse şayet, hâlâ hamsin

kandil gibi tamamen yan da, kâmil olasın.

Ayrıca, Hindistan'da nefes kontrolü egzersizi yapan bir yogi topluluğu da vardır. Bu yogiler, sözkonusu egzersizde yılmaz bir sebat ile öyle bir seviyeye varırlar ki birkaç günlük aralarla yalnızca tek nefes alır ve bu mahareti zirve bir mükemmeliyet ve en büyük başarı olarak görürler. Benares şehrinde bu yogilerden biri vardı ki bu maharette çok üstün bir seviyedeydi. Öyle ki Hân-1 Zaman bir defasinda bu yogiyi on günden fazla bir süreyle toprağa gömdü. Başka bir defasındaysa bu yogi, yine Hân-1 Zaman tarafindan yaklaşık yirmi gün boyunca tıpkı bir gemi çapası gibi su altında tutuldu. Ama yogi hiçbir sıkıntı yaşamadı. Başka bir örnek olarak, Pencap bölgesinde de 'dünyevi bağlar'dan kurtulmuş 'deli' bir 
adam vardi. Bu adam her iki dünyanın zenginliklerini de bir kenara fırlatmış, ne dünya ne de dünyacı insanlarla hiç irtibatı kalmamıştı. (Şiir:)

Gözlerindeki kirpiklerden birer zambak uzanır,

ve bakışlarını kötü ve iyi zamanlardan azade kılar.

Bu yogi bütün hayatı boyunca küçük bir toprak parçası üzerinde yaşıyor, kalp cevherinin hazinesi demek olan sol göğsünü bu toprak parçasındaki gediğe yaslıyordu. Ellerini yiyeceklere uzanmaktan alıkoyuyor ve pinekleme hali içinde gözlerini kapalı tutuyordu. Zikri geçen Muhammed Yusuf, kendi yazdığına göre, bu yogiyi görmüştür. Dahası, Muhammed Yusufun bu yogiye yakın insanlardan duyduğuna göre, sözkonusu yogi yirmi iki yll boyunca böylesi bir perhiz uygulamasından şaşmamıştır. Sözkonusu yogi bütün bu zaman boyunca ayaklarını kımıldatmamış ve ellerini de açmamıştı. Beslenme olaraksa sadece yemek kokusuyla idare etmişti. Allah yardımcıların en büyügüüdür! ${ }^{26}$

Burada, kendisini canlı canlı yakan ve -ilk dönem Hiristiyan münzevilere 'rakip' olması telakkisiyle- insanüstü bir münzevi olarak yaşayan acayip bir yogi tasviri; Fars şiirinin zirve mahsullerinden çıkarsanmış kelimelerle sergilenmektedir.

Yogilerin nefes kontrolü ile alakalı olarak Müslümanların kullandığ1 tekniklerden biri, bir edebiyat antolojisinde yer almaktadır. Bu antoloji, Şîr Han Lodi'nin 1690 yllında Bengal'de derlediği Mir'âtül-Hayâl (Hayal Aynası) başlıklı çalışmadır. Şîr Han, öğretmeni Nazım'dan (vef. 1657) bahsettiği sırada yer verdiği bir ara fasılda, bu zatın sadece şair olmakla kalmayıp aynı zamanda geleceği tahmin etme amaçlı olmak üzere nefes kontrolü sanatında maharetli bir remmâl (remil ile fal bakan) olduğunu söylemektedir. Şîr Han'’n müşahedesine göre bu maharet; Yunan, Irak ve Horasan geleneklerinde bilinmemekte, aksine, Hindistan yogilerinden kaynaklanmaktadır. Şîr Han'ın küçük risalesi, sağ ve sol burun delikleriyle bağlantılı olmak üzere 'güneş ve ay nefesleri' üzerinde

26 Rází, Haft Iqlím: II:509-11. Bu tahkikli Farsça nüsha, 1950’lerde basılmış Tahran nüshasına göre önemli ölçüde daha muteber durumdadır. 
ayrıntılar verdiği gibi savaşta başarılı olmak, hastalıklarla mücadele etmek ve geleceği tahmin etmek gibi konularda bu nefeslerin nasıl kullanılacağı ile alakalı geniş bilgiler vermektedir. Şîr Han bu 'bilim'in kaynağını Mahadev'in (Şiva) karısı Parvati'ye aktardığ öğretilere dayandırmaktadır. Ancak, öyle anlaşılmaktadır ki Şîr Han, Bengal'deki güçlü yoga geleneğinden haberdar değildir; çünkü en başarılı yogiler olarak Keşmir yogilerini zikretmektedir. Şîr Han (neredeyse sonradan akla gelen bir düşünce olarak) yogilerin kendi öğretilerini aynı zamanda $\mathrm{Hz}$. Adem'den almış olabilecekleri sonucuna varmaktadır; çünkü bu düşünce, Bengisu Havuzu (The Pool of Nectar) olarak bilinen Arapça çalışmada yogiler tarafindan kabul edilmektedir. Yine de bu düşünce yoga olgusunun Hint karakterini muhafaza etmektedir, çünkü Hz. Adem'in Seylan'da bir bahçeye nüzûl ettiği hemen herkesçe bilinen bir 'husus'tur. ${ }^{27}$ Şîr Han'ın, aynı zamanda, ilahi bir Hint mualliminin İslami mukabili olarak Hz. Adem yerine Hz. İbrahim'i ikame eden Bengisu Havuru'na bir göndermede bulunmasi; bu metnin alternatif bir nüshasinin (ya da muhtemel bir 'sürç-i lisan') göstergesi olarak değerlendirilebilmektedir.

Hindistan'a yaptığı seyahatleri kayıt altına alan bir başka seyyah, Belh'den başlayıp Hindistan ve Seylan'a ve aynı istikamette Belh'e doğru birer seyahat gerçekleştiren ve yedi y1l süren bu seyahatleri üzerine 1631 yılında tamamladığı bir seyahat anıları kitabı yazan Mahmud İbn Emir Velî Belhî’dir. ${ }^{28}$ Kendi özel tercihleri doğrultusunda seyahat ettiği anlaşılan Belhî, -Mathura'daki Raja Man Singh mabedi, Acmer'deki Muinüddin Çeştî türbesi ve Orissa'daki Konarak ve Jagnnath mabetleri gibi- Hindistan'daki birçok önemli türbe-külliyelere yaptığ1 ziyaretleri anlatmaktadır. Belhî; seyahatlerine henüz başladığı Peşaver yakınlarında, Moğol hükümdarları Babür ve Cihangir tarafindan da kısa süreli olarak

27 Virolleaud, "Sur un épitomé." Şair Nazım (vef. 1068/1657), aslen Herat’llysa da ömrünün çoğunu İslamabad'da (Dhaka) geçirmiştir. Bu zat, Hz. Yusuf ve Züleyha kıssası üzerine popüler bir mesnevinin yazarı olan hemşerisi Nazım Herevî (vef. 1082/1671) ile karıştırılmamalıdır (Storey, I:823, n. 3). Şîr Han gençliğinde şair Nazım'dan kısa süreli bir eğitim görmüştür.

28 Belhî, Bahru'l-Esrâr, pp. 4-6 (Farsça metin), pp. 31-32 (İngilizce giriş yazıs1). Karşılaştırınız: Storey, I:375. Bu bölüm şurada tamamen tercüme edilmiş olarak bulunabilir: Hussain, "Hindu Shrines and Practices," pp. 142-144; ayrica bkz.: Foltz. 
ziyaret edilen yogi 'zaviye'sine uğramıştır. Ancak, tıpk1 Babür ve Cihangir'in ziyaretlerinde olduğu gibi Belhî’nin ziyareti de, benzer şekilde, bilgi devşirme açısından verimsiz olduğu kadar hayal kırıklı̆̆ına uğratıcıydı. Nefes kontrolü uygulaması gerçekleştiren yogilere "zahit" diye göndermede bulunan Belhî, taş ve briketten yapılma yüksek 'zaviye'lerini baş üstadın bin rakamına baliğ takipçilerini barındıran bir mekân olarak nitelendirmektedir. Belhî’nin bir miktar hakaretâmiz şekilde kaydettiğine göre bu "sapkın mezhep," mükemmeliyetin en yüksek alametinin, nefesi gün boyu tutabilmek olduğu fikrini benimsemektedir: bu marifete nâil olan yogi, zaviyenin üstadı olarak baş tacı edilmektedir ve bu arada sabık üstat, "ebedi azaba mahkûm olmak üzere birkaç gün içinde kesin olarak cehenneme gitmesi için hapsedilmektedir." Müteveffa üstadın ruhunun, çok geçmeden, kendi kemâlâtına uyan başka ve daha iyi bir bedene intikal edeceği farz edilmektedir. Belhî’nin müşahedesine göre o bölgenin halk1 ve krallan, yogilerin bu zaviyesini ayni ve nakdi yardımlarla desteklemektedir. Dahası Belhî, zaviyenin "düşmansılık ya da önyarg1 adına hiçbir alamet izhar etmeyen" yeni üstadıyla konuşmuş ve yine kendi iddiasına göre - tevhid inanışına dair kanıtlar sergilemek ve böylece doğrudan doğruya mahcup düşürmek suretiyle onu teolojik anlamda çürütmüştür. Belhî’nin kaydettiğine göre kocaman biyıklı bir başka yogi, sürekli taşıdığı ağır zincirlerle geniş bir hayran kitlesi kazanmıştır. Belhî’nin değerlendirmeleri açısından da yogiler, esas itibarıyla, seyyahlar tarafindan biraz küçümsemeyle gözlemlenen merak konusu insanlar olarak görülmektedirler.

Yogilere ilişkin benzeri bir tasvir, İranlı tüccar Mîr Abdüllatif Han Şuşterî̀nin seyahat anlatısında bulunmaktadır. Şuşterî ilk olarak Hindistan'a 1788 yllında gelmiş, Bengal bölgesinin İngiliz idaresi altında memur olarak çalışmış ve daha sonra da kuzey Hindistan ve Dekkan bölgelerinde çokça seyahat etmiştir. $\mathrm{Bu}$ seyahatlerinin, sağllk sebeplerinden olduğu kadar ailevi sebeplerden de kaynaklanmasi sözkonusuydu. 1804 yılında tamamladığ1 kişisel hatıratı, Hint kültürü üzerine genel olarak olumlu yorumlar ihtiva etmektedir. Yogilere ilişkin şüpheci düşünceleri, yogilerin gerçekleştirdiği uygulamalara dair geniş ölçekte tedavül eden masallar için bir gösterge işlevindedir. Şuşterî, bilhassa, kendilerini kılıçlar ve bıçaklar kuşanmış olarak Himalayalar'da 
coşkun akan nehirlere ya da yağlanıp açı havada yakılan şenlik ateşlerine atmak suretiyle 'intihar eden' yogilere dair hikâyeler anlatmaktadır:

Genellikle tarihçiler, Hindistan kültür coğrafyasını ve Hindistan münzevilerini övmede çok aşırıya giderler. . . . Bu tarihçilerin söylediklerine göre, Hindistan münzevileri şöyle yapar: Sind dağlarından kaynaklanan geniş ve gür bir nehirde son derece güçlü, yoğun, mecrası boyunca kayalara ve küçük tepelere çarpan ve görünümü şiddetli korku veren bir akıntı vardır. Bu nehrin kaynağının yakınlarındaki dağın ardında, nehrin üzerinde adeta bir gölge gibi uzanan ve "kund" dedikleri bir mevki vardır. "Menba" anlamına gelen "kund," -Farsça "kaba, katı" anlamına gelen- "tund" kelimesiyle kafiyeleşmektedir. Dağın doruk noktasından nehir mecrasının başladığı noktaya kadar sıra sıra büyük ağaçlarla dolu bir alan mevcuttur. Bu ağaçların ve kenarlarındaki kayalıkların üzerine bıçak, kılıç ve diğer kesici aletler yerleştirilmiştir. Ruhlarının bir kralın bedeninde tekrar hayat bulması (enkarnasyon) ödülüne nail olmak amacıyla münzeviler, dağın tepesinden bu mevkiye doğru atlar ki sözkonusu 'güzergâh' boyunca organları parçalara ayrılsın ve en nihayet suda boğulsunlar.

Bunun dışında Hindistan münzevileri, kendilerini ateşte yakarlar. Şöyle ki: Öncelikle kraldan izin ister ve yerleşim yeri dışında büyük bir ateş yakarak 'ebedi mükâfata nail olmak amacıyla falan kimse belli bir gün ve belli bir yerde kendisini ateşe atacak' diye ilan ettirirler. Insanlar bu münzevinin evinin çevresine, kapısının önüne doluşur ve şehirde büyük bir kargaşa meydana gelir. Evinden dışarı çıkan münzevi şatafatlı elbiseler giyer ve hem bedenini hem de elbiselerini yağ, kükürt ve kırmızı ardıç ağacı sakızıyla ovar. Sonra, alevli bir demir ya da gümüş tütsü kabını çıplak başının üstüne koyar, başının bir tarafına bir miktar bitki yerleştirir. $\mathrm{Bu}$ sırada akrabaları ve diğer insanlar kükürt ve kırmızı ardıç sakızı buhurunu içlerine çekerler. Yavaş yavaş insanlar, şarkı söyleyen ve dans eden bir grup haline gelirler. Münzevi, mutluluk ve neşe hali içinde betel ağac1 yaprağ1 yer, sokaklar ve pazar yeri boyunca yürüyerek izleyiciler arasında önceden kendini tanıyan her bir kimseye sözkonusu bitkilerden bir miktar verir ve bu kimse için dua eder. Söylendiğine göre bu münzevinin duası makbul olmak gibi bir özelliğe sahiptir. Böylece münzevi şehir merkezinin dişına çıkar ve kendini ateşe atar. Bu eylemi gerçekleştiren bazı münzeviler, yanan ateşin yakınına gelip bir bıçak ile kimi uzuvlarını teker teker keser ve ateşe atarlar. Bazıları da ateşin 
yakınında karınlarını kesip ciğerlerini çıkarır ve parçalara ayırıp ateşe atarlar. Sonra da kendileri ateşe atlarlar. Şayet yanan ateşe tam olarak giremezlerse, bu kez, diğer insanlar onları ateşe iterler. ${ }^{29}$

Her iki hikâye de; yogilerin kendi organlarını kesmeleriyle ilgili olarak dehşetli sahneler ihtiva etmektedir. Bu sahneler, [bir yoga pozisyonu unsuru olarak] 'ip numarası' örneğinde olduğu gibi 'yogi safahatı'nın temel özelliği olarak ritüel 'parçalama simgeselliği’ni yansitmaktadir. ${ }^{30}$

Şuşterî, yogilerin nefes tutma becerilerinden de bahseder. Bu nefes tutma becerisine ilişkin popüler kültürdeki anlatılar, yüzyıllar boyunca yeraltında gömülü olup bir bakır plaka üzerinde yazılı tarihte tekrar canlanan yogilerden söz etmektedir. Bu bağlamda Şuşterî, şöyle bir yorumda bulunmaktadır: "Her ne kadar eski tarihçiler Hint münzevileri hakkındaki bu hikâyeleri nakletmişlerse de ve ayrıca bu hikâyeler halen ağızdan ağıza tedavül ediyorsa da (şahsen bu hikâyelerden çok miktarda duymuş bulunuyorum), sağlıklı zihin ve muhkem akıl bu tür hikâyelerin doğruluğunu ve gerçekliğini tamamen reddeder. . . . Bu hikâyeler sahtedir ve katıksız yalanlardan ibarettir." ${ }^{31}$ 'Ölümsüz yogiler' fikrini kabul etmemesine rağmen Şuşterî, 'nefes kontrolü' uygulayıcılarının -özellikle de Dekkan'da gördüğü ve havada yükselme mahareti sergiyen yogilerinmevcudiyetini itiraf etmektedir. Haydarabad'da böylesi bir yogi ile sözkonusu maharetini gerçekleştirebilme sebeplerine dair mülakat yaptı̆̆ında; kendisine, bütün efsanevi uygulamaların ötesinde, nefes kontrolü uygulamasinı mükemmelleştirme yolunun 'meni tutma' uygulaması olduğu söylenmiştir. Bu yogi, Şuşterî̀ye, cima sırasında nefes kontrolü uygulamasını denemesi gerektiğini tavsiye etmiş; çünkü yaşlanmanın başlıca sebebinin 'meni kaybı' olduğunu söylemiştir. Yogiler nefesle ilgili olarak böylesi bir kontrol gücüne sahip olduklarını iddia ettikleri gibi 'damardan emme' yoluyla süt dolu bir bardağ boşaltabildiklerini de iddia etmişlerdir. Dikkatlice bir düşünme

Şuşterî, Tubfetü'l-'Alâm, pp. 349-51.

30 Eliade, Yoga, 322-23, 336, 347.

31 Şuşterî, p. 449. 
ameliyesine dayalı olarak Şuşterî, nefes kontrolü ve 'meni tutma' yeteneğinin Yunan-Arap tıp teorisinin 1şı̆̆ altında anlaşılması gerektiği sonucuna varmıştır: "[Bu teoriyi] İbn-i Sina'nın Kanun başlıklı kitabında ya da adını hatırlamadığım bir başka kitabında görmüştüm." Şuşterî yoga tekniklerinin 'haz aşıkları'nın cinsel numaralarından daha iyi olmadığına dair bir sonuca varır ve konu üzerinde daha fazla durarak okuyucularının canını sıkmak istemediğini söyler. ${ }^{32}$

Hindistan sahnesinin asıl parçalarından biri olarak yogiler, Moğol İmparatorluğunun resmi tarih ve coğrafya kamuslarında sürekli şekilde Hindu toplumun kabul edilmiş bir kesimi olarak tasvir edilmişlerdir. Yogilere ilişkin böylesi bir resmi değerlendirme, Sujan Ray Bhandari'nin 1695-1696 yılları arasında tamamladığ Hulâsatu't-Tevârîh (Tariblerin Özeti) başlıklı Farsça kitabında bulunmaktadır. Kapsamlı bir Hindistan tarihi içermesine ve Moğol İmparatorluğu eyaletlerine ilişkin istatistiki rakamlar ve tasvirler ihtiva etmesine ilave olarak bu kitap, Hindistan sakinleri, âdetleri ve iklim farklılıklarına dair değerlendirmeler sunmaktadır. Bir yüzyıl sonra Hindistan'daki İngilizler bu metni son derece faydalı bulmuş olsalar gerektir ki Kalküta'nın (Calcutta) Fort William mintıkasındaki Hindistanlı baş öğretmen Şir Ali Han Efsus'u (vef. 1809) bu metnin Urduca bir tercümesini yapması için görevlendirdiler. Adı geçen zat da bu metni Arâyiş-i Mahfil (Meclis Süsleri: The Adornment of the Assembly) başlı̆̆ıla Urducaya tercüme etmiştir. Bu tercüme metin, Hindistanlıları inceleyen Doğu Hint Şirketi (East India Company) teşkilatı memurları için standart bir metin haline gelmiş ve İngilizceye ya da Fransızcaya en az yedi defa tercüme edilmiştir. Bu metnin Hint fakirleri ile alakalı bölümü; Hint dilencilerini (sannyasi), yogileri, Beragi'leri, Nanak Panthi'leri, Jatis Seora'ları, dört inzivâhane (ashram) ve sosyal sınıfı (kast) tasvir etmektedir. Yogiler ile alakalı alt bölümde şunlar yazılmıştır:

Onlar gece gündüz Allah'ı zikretmekte ve uzun süreler boyunca nefeslerini tutabilme (babs-i dem) yetenekleriyle yüzyllarca yaşamaktadırlar. Sıkı davranış tasarruflarıyla (riyažet, yani, yoga) dünyevi elbiseleri (yani, bedenleri) öylesine hafiflemiştir ki havada uçabilir ve denizde yürüyebilirler. İcra ettikleri faaliyetlerin kuvvetiyle her istediklerinde ruhlarının uçmasını, arzu ettikleri şekli almasını, bir başka

32 Şuşterî, pp. 450-51. 
insanın bedenine girmesini ve gizli âlemden haber vermesini sağlayabilirler. Küllerin içine koydukları bakırı altına dönüştürebilirler ve büyülerinin gücüyle bütün dünyanın hayranlığını çekerler. Ölüm döşeğindeki hasta bir insanı anında iyileştirebilir ve diğer insanların kalplerinden geçenleri derhal anlayabilirler. Bu kimselerin âdetleri, hiçbir bakıcı ve tanıdık edinmemektir. "Yogilerin hiçbir aşina arkadaşlarının olmadığı" doğrudur. Hint münzevi dilencileri (sannyasiler) büyü, efsunculuk, simya ve kimya konularında muazzam yetenekli olsalar da, yogilerin bu sayılan alanlardaki yetenekleri çok daha meşhurdur. ${ }^{33}$

Aslında dünyayı terk eden sufiler için kullanılan Arapça kökenli fakir terimi, büyük ihtimalle Farsça ve Urduca kaynakların etkisiyle, itibari anlamda ister Hindu isterse Müslüman olsun herhangi bir münzeviye delalet etmek üzere İngilizceye fakeer olarak geçmiştir. Bu kaynağın gösterdiğine göre, on yedinci yüzyılın başlarında fakir terimi Hindistan'da yogiler için yaygın olarak kullanılmaktaydı ve Avrupalılar da terimin bu anlamda kullanımını hızla benimsemiş oldular. ${ }^{34}$ Yukarıda zikredilen iktibas, nefes kontrolü ve yoga disiplinine ilişkin uygulamalardan söz etmekteyse de esas itibarıyla yogilere isnat edilen gizem ve mucizevi güçlere dair popüler hayranlığ1 göstermektedir. Ekseriya tasavvuf tarikatlarına paralel bu ve benzeri yogi tasvirleri, diğer Moğol coğrafya sözlüklerinde de bulunabilmektedir. Örneğin Ray Chaturman'ın (yaklaş1k vefat tarihi: 1759) Cehâr Gülşen’i (Dört Bahçe: Chahar Gulshan); bütün İslam dünyasına şamil olmak üzere on iki silsilevî tasavvuf tarikatı, Hindistan'a özgü on dört sufi 'banvada's1 ("aile") ve Hint münzevilerinin mensup olduğu altı 'derşan' (okul) saymaktadır. ${ }^{35}$

33 Afsus, The Araish-i-Mahfil, trans. Court, p. 39-40. Bu kaynak, Arâyişs-i Mabfilin Urduca metni baz alınarak tadil edilmiştir. Bkz.: Arâyiş-i Mahfil (Urduca), p. 53. Farsça orijinal metin ve farklı birkaç tercüme için bkz.: Storey, Persian Literature, I:454-58.

34 Yule \& Burnell, Hobson-Jobson, pp. 347b-48a, s.v. "fakeer"; Crooke, Things Indian, pp. 199-204 (bu kaynak, Barbosa, Bernier, Fryer, ve Colebrooke’u iktibas etmektedir); Eliade, Yoga, pp. 423-25.

35 Ray Chaturman, Chahar Gulshan, fols. 127a-141. 
Moğol İmparatorluğunun resmi coğrafya kamusları daha sonraki İngiliz müstemleke idaresinin araştırmalarını 'öngörmüş' ve muhtemelen bu araştırmalar için bir nevi model sağlamıştır. Bu araştırmalar, Hindistan'daki değişik kast, meslek ve din gruplarını ayrıntıyla ele almıştır. Başka bir makalemde de incelediğim gibi İngilizler, Hindistan'ın âdetlerini ve dini mezheplerini inceleyen birçok Farsça metin kullanmıştır. ${ }^{36}$ Ingilizlerin Hindistan hâkimiyeti dönemimin ilk yıllarından kalan bir başka metin, Silsile-i Cogivân (Cogilerin Tarikatlar) başlı̆̆ını taşımaktadır (faal devlet hizmetinde kullanılmaya başlandığı yıl: 1800). Cogilere dair resimli bir tetkik niteliğinde ve Farsça yazılmış olan bu metin, değişik riyazet tarikatlarının göstergesi olarak karikatür benzeri küçük minyatürler de ihtiva etmektedir. Farsça ifadelerin İngilizce okunuşları itibarıyla Latin harflerine dönüştürülmüş şekilleri (İngilizce transliterasyon) kitabın içindeki resimlere alt yazı halinde kurşun kalemle yazılmış bulunmaktadır. Ayrıca bu çalışma, Benares şehrinin nüfusuna ilişkin maliye istatistiği içeren bir ek içermektedir. Kitap üç bölümden oluşmaktadır: Vaisnava (on altı tarikat içermektedir), Şaiva (on dokuz tarikat içermektedir) ve "Şaktik" (diğer bir deyişle, Şakti: her biri alt bölüm içeren beş ana tarikat içermektedir. Tuhaf bir şekilde bu tarikatlar Hindular arasinda münzevi ve sürekli ilahi okuyan kimseler demek olan 'Sant'ları ve Sihleri de kapsamaktadır). Bu kitabın başlığındaki cogi (yogi) kelimesi, Hindistan'daki bütün örgütlü münzevi toplulukları kapsayacak şekilde kullanılmıştır. Daha özel bir anlamıla cogi kelimesi, Nath ya da Kanphata ("yarrk-kulak") yogilerine delalet eden bir terim olarak da kullanilmaktadır. Silsile-i Cogiyân'da bu yogiler, isabetli bir tasnif olarak Şaiva tarikatları kapsamında zikredilmektedir:

$\mathrm{Bu}$ yolun ilk kurucu siması Mahadeva [Şiva], ve onun halefleri olan Gorakhnath ve Machhindirnath [Matsyendranath] idi. Yogay1 ve halen bilinen kuralların ilk tesis eden bu simalar oldu. Bu mezhebin önderleri; eski zamanlarda yaşamış, vahiy (revelation) alan ve mucize gösteren insanlardı. Çok güçlü bir iradeye sahip bu insanlar, gençken de yaşlıyken de aynı minval üzere yaşamış, ölmekten hiç korkmamışlardır. Göğe yükselme ve ortadan kaybolma yeteneğine sahip olan bu insanlar başkaca benzeri olağanüstü olaylar gösterebilmekteydiler. Günümüzdeki

36 Ernst, "Muslim Studies." 
cogiler, şöyle bir din(darlık) yolu takip ederler: Cogiler, yeni müritlerinin bir kulağını kıkırdak kısmından deler ve deldikleri yere, balina kemiği (Hindi lisaniyla: kackeara), kristal ya da benzeri bir cisimden mamul bir küpe takarlar. Bu kulak delinmesi (Arapçasiyla: şakku'l-ǚün) vesilesiyle müritler, bir daha asla dünyaya düşkünlük göstermezler. Kalp tasfiyesi, nefes kontrolü ve beden eğitimi uygulamalarını gerçekleştirirler. Vücutlarına kül süren bu cogiler, başlarına bir şapka takar, yamalı bir üstlük giyer ve boyunlarına da demir bir orak (Hindistan'n kuzey taraflarında konuşulan Hindi lisanıyla: sabbal) takarlar. Bütün gençliklerini çok ağır eziyet ve cefa uygulamaları içinde geçirirler. Bazıları da Bhairoñ'un [Şiva'nın bir tecellisi olarak Bhairava] ve Hanuman'ın takipçisi olmuştur. Et ve şarap tüketiminden sakınmayan Bhairoñ ve Hamuman'ın eğitim enstitüleri sefahat ve ayyaşlık düşkünü yerler olarak bilinmektedir. ${ }^{37}$

'Cogi'lerin benimsediği 'kurucu mitoloji'yi mevcut ritüelleri ve olağanüstü olaylar gösterme/icra etme yetenekleriyle birleştiren bu iktibas dahi yüzeysel bir değerlendirmedir. 'Cogi'lerin sansasyonel itibarı ve renkli görünümlerine ilişkin bu tasvir, (bu) "mezheb”e yönelik resmi yaklaşıma paralel bir yargı aksettirmektedir.

Hem tarih hem de seyahat metinlerinin değerlendirmeleri, 'dış gözlemci’nin yoga öğretisine aşina olma sürecinde yaşayacağı zorlukları göstermektedir. Her şeyden önce, yogilerle ilgili olarak tedavül eden renkli efsanelerin oluşturduğu -ve yogilerin "inan ya da inanma" kabilinden büyülü masalların kahramanı olarak işlev gördüğü, dolayısıyla, tetkik hamlelerinin aşması gereken- muazzam bir 'yanılsama katmanı' sözkonusudur. Yanısıra, karşılaşılan yogilerin pekâlâ bir sahtekâr ya da en iyi şartlarda yoga geleneğine dair kısmen bilgili olma ihtimali sözkonusudur. Bütün bu ihtimallerin dışında, yogilerin dış gözlemcilere, özellikle ilgi duyacakları hususlar1 hesaba katarak ya da mülakat yapanların bakış açısına paralel düşecek bir tarzda açıklama yaparak sadece parça-buçuk bilgiler aktarma ihtimali sözkonusudur. Son olarak da, Farsça eğitim görmüş dış gözlemci (daha sonraları da İngilizce eğitim

37 Anonymous, Silsile-i Jugiyan, fasiküller: 19a-20a. (61a no'lu fasikülde Miladi 1800 y1lı verilmektetir. Gelir istatistikleri de 60a-71a no'lu fasiküller arasında yer almaktadır). 
görmüş dış gözlemci), ister istemez, yogilerin açıklamalarını Hint dış1 kaynaklara dayalı ve dolayısıyla tamamen farklı bir kozmolojik sistem açısından yorumlayacaktır. Müslüman seyyahların yogilere karşı takındığ1 tavırlarda İslami önyarg1lar (biases) belli bir etkiye sahiptir; ancak, bizzat yoga uygulaması hayret edilesi ya da bilimsel olarak açıklanmaya muhtaç acayip bir başarı olarak yorumlanma eğilimindedir. Hindistan Moğol idaresi dönemindeki Hintli-Müslümanların yabancı temayülü (exoticism); tabii devamlılı̆̆ını, İngiliz müstemleke idaresi dönemindeki yazılı antropolojik mahsullerde bulacaktır. Bir dereceye kadar şaşırtıcı bir gelişme olarak kaydetmek gerekir ki yoga olgusunun en bilgili Müslüman gözlemcilerinin, krallar (sultanlar) olduğu görülmektedir. Bunun sebebinin, sözkonusu kralların batıni (esoteric) spiritüaliteye özellikle ilgi duymalarından değil de, yogilerin gizemli güçlerini kendi siyasi emellerini takviye edici payanda olarak görmelerinden kaynaklandı̆̆1 ortaya çıkmaktadır. 


\section{KAYNAKÇA}

Abu al-Fazl 'Allami. The A'in-i Akbari. H. S. Jarrett, trans., Jadunath Sarkar, revised 2nd ed., Calcutta, 1948; reprint ed., New Delhi, 1978.

The Akbar nama of Abu-l-Fąl: History of the Reign of Akbar Including an Account of His Predecessors. Henry Beveridge, trans. Delhi, 1977 [1902].

Alam, Muzaffar \& Sanjay Subrahmanyam. "Empiricism of the Heart: Close Encounters in an 18th-Century Indo-Persian Text." Studies in History 15/2, n.s. (1999): 261-291.

Anomim (bilinmeyen yazar). Silsile-i Cugiyân. MS 2974 Ethé, India Office Library, London (McKenzie MS 3087).

Babur Padshah Ghazi, Zahiru'd-din Muhammad. Babur-nama Memoirs of Babur). Annette Susannah Beveridge, trans. New Delhi, 1979 [1922].

The Baburnama: Memoirs of Babur, Prince and Emperor. W. M.Thackston, Jr., trans. Washington, D.C, 1996.

Bada'uni, 'Abd al-Qadir ibn Muluk Shah. Muntakhab ut-tawarikh. George S. A. Ranking, W. H. Lowe \& Wolseley Haig, trans. 3 vols., Calcutta, 1898-1925.

Belhî, Mahmud Ibn Emir Veli. Bahru'l-Esrar fì Menâkibi'l-Ahyâr. Riazul Islam, ed., Karachi, 1980.

Bouillier, Véronique. Ascètes et rois: Un monastère de Kanphata Yogis au Népal. Paris, 1997.

Afsus, Shir `Ali Khan. Arayish-i Mahfil. Kalb `Ali Khan Fa'iq, ed., Urdu ka Klasiki Adab, 31. Lahore, 1963.

The Araish-i-mabfil; or, The Ornament of the Assembly. Henry Court, trans. 2nd ed., Calcutta, 1882.

Chaturman, Ray. Chahar Gulshan. MS 542, H.L. 92, Khudabakhsh Library, Patna. 
Cole, Juan. "Mirror of the World: Iranian 'Orientalism' and Early 19thCentury India." Critique: Journal of Critical Studies of Iran and the Middle East (Spring 1996): 41-60.

Crooke, William. Things Indian: Being Discursive Notes on Various Subjects Connected with India. London, 1906.

Digby, Simon. "Encounters with Jogis in Indian Sufi Hagiography." Unpublished paper presented at the Seminar on Aspects of Religion in South Asia, University of London, January 1970.

Eliade, Mircea. Yoga: Immortality and Freedom. Willard R. Trask, trans., Bollingen Series, LVI. $2^{\text {nd }}$ ed., Princeton, 1969.

Ernst, Carl W. "Situating Sufism and Yoga." Journal of the Royal Asiatic Society, Series 3, 15:1 (2005): 15-43.

"The Islamization of Yoga in the Amrtakunda Translations." Journal of the Royal Asiatic Society, Series 3, 13:2 (2003): 199-226.

"Muslim Studies of Hinduism? A Reconsideration of Persian and Arabic Translations from Sanskrit." Iranian Studies 36 (2003): 17395.

"Admiring the Works of the Ancients: The Ellora Temples as Viewed by Indo-Muslim Authors." In Beyond Turk and Hindu: Retbinking Religious Identities in Islamicate South Asia, ed. David Gilmartin \& Bruce B. Lawrence. Gainseville, FL: University Press of Florida, 2000. 198-220.

Foltz, R. 1996. "Two Seventeenth-Century Central Asian Travellers to Mughal India." Journal of the Royal Asiatic Society, 6 (1997): 367-77.

Goswamy, B. N. \& J. S. Grewal. The Mughals and the Jogis of Jakhbar: Some Madad-i-Ma ash and Other Documents. Simla, 1967.

Green, Nile. "A Persian Sufi in British India: The Travels of Mîrzâ Hasan Safî 'Alî Shâh (1251/1835-1316/1899)." Iran: Journal of Persian Studies 42 (2004): 201-18.

Husain, Iqbal. 1999. "Hindu Shrines and Practices as Described by a Central Asian Traveller in the First Half of the 17th Century." In Irfan Habib, ed., Medieval india 1: Researches in the History of India 1200-1750. Delhi, 1992, pp. 141-153. 
Ibn Battutah. Travels in Asia and Africa 1325-1354. H. A. R. Gibb, trans., E. Denison Ross \& Eileen Power, ed. London, 1929; reprint ed., Karachi, 1986.

Voyages d'Ibn Battuta. C. Defremery \& Beniamino Raffaello Sanguinetti, ed. and trans. Paris, 1968-1969.

Jahangir. The Tuzuk-i-Jahangiri or Memoirs of Jahangir. Alexander Rogers, trans., Henry Beveridge, ed. 2 vols., Lahore, 1974 [1909].

The Jahangirnama: Memoirs of Jahangir, Emperor of India. W. M.Thackston, Jr., trans., Washington, D.C., 1999.

Jhavery, Mohanlal Bhagwandas. Comparative and Critical Study of Mantrasastra (With Special Treatment of Jain Mantravada). Sri Jain Kala Sahitya Samsodhak Series, no. 1. Ahmedabad, n.d.

Mobad Şah [Muhsin Fani, (isnat edilen yazar)]. Debistâni'l-Mezâbib. Bombay, 1262/1846.

The Dabistan: or, School of Manners: The Religious Beliefs, Observances, Philosophic Opinions and Social Customs of the Nations of the East. David Shea, trans. Washington, 1901.

Nath, R. \& Faiyaz 'Gwaliari'. India as Seen by Amir Khusrau (in 1318 A.D.). Jaipur, 1981.

Rází, Amín Ahmad. Haft Iqlím: The Geographical and Biographical Encyclopaedia. M. Ishaque, ed. Bibliotheca Indica, 287. Calcutta, 1963

Re'is, Seyyidi 'Ali. Le miroir des pays: Une anabase ottomane a travers l'inde et l'asie centrale. Jean-Louis Bacqué-Grammont, trans. Arles, 1999.

Rizvi, Athar Abbas. A History of Sufism in India. Vol. 1, Early Sufism and its History in India to 1600 AD. New Delhi, 1975.

Schmidt, Richard. Fakire und Fakirtum im alten und modernen Indien; Yogalebre und Yoga-praxis. Berlin, 1907.

Şuşterî, Mir Abdüllatif Han. Tubfetü'l-'Alâm vea Zeylu't-Tubfe. Samed Muvahhid, ed. Tahran, 1363/1984. 
Siddiqui, I. H. "Resurgence of Chishti Silsila in the Sultanate of Delhi." In Christian W. Troll, ed. Islam in India: Studies and Commentaries. Vol. II, Religion and Religious Education. Delhi, 1985, pp. 58-72.

Storey, C. A. Persian Literature: A Bio-bibliographical Survey. London, 1970.

Strabo. Geography. Horace Leonard Jones \& J. R. Sitlington Sterrett, ed. and trans. London, 1917.

Sulayman (eserin isnat edildiği yazar). 'Abbar as-Sin wa l-Hind, Relation de la Chine et de l'Inde rédigé en [237]/851. Jean Sauvaget, ed., Paris, 1948.

al-Ulughkhani Hajji ad-Dabir, Abdullah Muhammad al-Makki al-Asafi. Zafar ul Walih bi Muzaffar wa Alib: An Arabic History of Gujarat. M. F. Lokhandwala, trans. 2 vols., Baroda, 1970-4.

Virolleaud, Ch. "Sur un épitomé de la science du souffle rédigé en persan." Journal Asiatique 235 (1946-7): 113-21.

White, David Gordon. "The Wonders of Sri Mastnath." In Donald S. Lopez, Jr., ed., The Religions of India in Practice. Princeton, 1995, pp. 399-411.

Yule, Henry \& A.C. Burnell. Hobson-Jobson, A Glossary of Colloquial AngloIndian Words and Phrases. William Crooke, ed., London, 1903; reprint ed., New Delhi, 1979. 